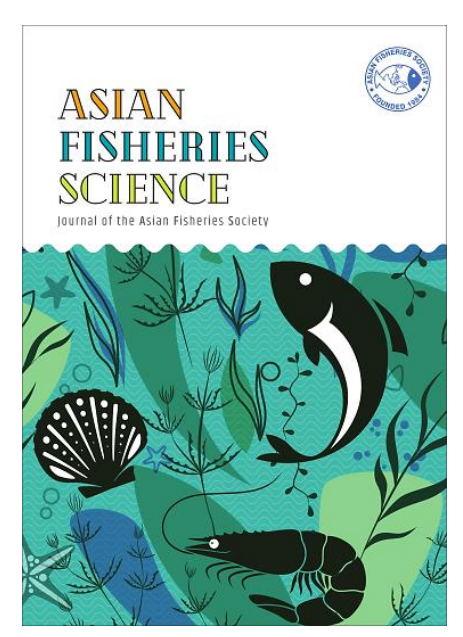

(c) Asian Fisheries Society

Published under a Creative Commons

license

E-ISSN: 2073-3720

https://doi.org/10.33997/j.afs.2021.34.4.001

\section{Seasonal and Spatial Distribution Patterns of Ichthyoplankton Along the West Coast of Sri Lanka}

\author{
ALANKARAGE PUBUDINI RANAHANSIKA SILVA ${ }^{1}$, RANKIRI PATHIRANNAHELAGE PRABATH \\ KRISHANTHA JAYASINGHE ${ }^{2 * *}$, MAHADURAGE ISHARA GIMHAN RATHNASURIYA ${ }^{2,3}$, KAHAWE \\ PALLIYA GURUGE KSHANIKA PIYUMI GURUGE ${ }^{1}$, SISIRA HAPUTHANTRI ${ }^{2}$, PADMINI DALPADADO ${ }^{4}$ \\ ${ }^{1}$ Faculty of Animal Science and Export Agriculture, Uva Wellassa University, Passara Road, Badulla, Sri Lanka \\ ${ }^{2}$ National Aquatic Resources Research and Development Agency, Crow Island, Colombo 15, Sri Lanka \\ ${ }^{3}$ Faculty of Fisheries and Ocean Sciences, Ocean University of Sri Lanka, Mahawela Road, Tangalle, Sri Lanka \\ ${ }^{4}$ Institute of Marine Research (IMR), PO Box 1870 Nordnes, N-5817 Bergen, Norway
}

*E-mail: prabathj@nara.ac.Ik | Received: 04/05/2021; Accepted: 10/11/2021

\begin{abstract}
Fundamental understanding of fish resources has become a crucial need in Sri Lanka for the sustainable management of fish stocks. Knowledge of ichthyoplankton essential in identifying the spawning dynamics of fish is scarce in this region of the Indian Ocean. A survey was conducted in 2018 covering different monsoon seasons to monitor the abundance, distribution, and diversity of ichthyoplankton along the west coast of Sri Lanka. Samples collected using vertical and horizontal WP2 hauls showed a total of 4095 fish eggs, with identification possible only to 3 families: Clupeidae, Engraulidae, and Cynoglossidae and 465 larval fish belonging to 23 families. The most dominant families recorded were the Siganidae, Blenniidae, Clupeidae, Gobiidae, and Engraulidae, which highlight the importance of pelagic and demersal fish along the west coast. A significant temporal pattern in egg abundance was observed with the highest abundance in March (535 $\left.10 \mathrm{~m}^{-3}\right)$ in vertical WP2 net hauls. Furthermore, significant differences in spatial patterns of larval abundance were seen in vertical and horizontal samples. High larval fish abundances were recorded in March and during September - November, with northern regions generally having the highest abundances $\left(\sim 36\right.$ larvae $\left.10 \mathrm{~m}^{-3}\right)$. The spawning coincides with the productive southwest monsoon period (May to September). The high diversity and abundance of eggs and larvae recorded in this study indicate that the west coast is likely an important spawning and nursery ground for demersal and pelagic fish.
\end{abstract}

Keywords: fish eggs, larval fish, spatial distribution, species diversity, Indian Ocean

\section{Introduction}

Studies on the abundance and distribution of ichthyoplankton provide important information about spawning grounds and spawning time of fish species (Selvam et al., 2013; Örek and Mavruk, 2016). Information on fish eggs and larvae can also help to identify the locations of critical spawning habitats that should be protected to ensure the long-term sustainability of vulnerable fish populations (Sala et al., 2002). Furthermore, ichthyoplankton surveys can be used as a fisheries-independent indicator of the ecosystem health, estimating the species-specific spawning biomass and overall reproductive strategies (Lo et al., 2001; Aceves-Medina et al., 2003; Deepananda and Arsecularatne, 2013; Auth et al., 2018). Moreover, studies on the early developmental stages of fish are essential for monitoring and managing these resources (Shuai et al., 2016; Zacardi et al., 2017).

There are several studies conducted on monitoring spatial and temporal variation in ichthyoplankton diversity and abundance in the Indian Ocean and other tropical areas. A study on species composition, abundance, and distribution of larval fish carried out in the Bay of Bengal (BOB) by Lirdwitayaprasit et al. (2008) showed a generally restricted number of families in the region with high abundances recorded only sporadically. The highest average abundance of recorded larval fish was 485 larvae $1000 \mathrm{~m}^{-3}$, with the richest diversity in the Andaman Sea area (Lirdwitayaprasit et al., 2008). Bapat (1955) reported the occurrence of fish eggs almost throughout the 
year in the Gulf of Mannar and the Palk Bay area, with the greatest concentration of fish eggs in the former region.

A thorough and systematic ichthyoplankton survey program was carried out by the UNDP/FAO Pelagic Fishery Project, Cochin (1971-1979) along the southwest (SW) coast of India (George, 1989). These survey results showed that several pelagic fish species spawned off the SW coast of India, namely Sardinella longiceps (Valenciennes, 1847), Rastrelliger kanagurta (Cuvier, 1816), Auxis spp., and Stolephorus spp. almost throughout the year, in the entire range of their distribution and mainly on the shelf. The highest spawning activity of most commercial species, especially the pelagic, was observed during the southwest monsoon season. Immediately prior to and after the monsoon season also showed significant spawning with the least activity occurring during December to January (George, 1989). A study by Beckley et al. (2019), investigating the spatial variation of ichthyoplankton assemblages in the eastern Indian Ocean along the Kimberly region off north-western Australia, reported larvae representing 92 neritic and 21 mesopelagic families. In their study, distinct ichthyoplankton assemblages characterised the inner shelf such as Engraulidae and Gobiidae, outer shelf/slope by mixed neritic and mesopelagic taxa, and oceanic waters by mesopelagic taxa, particularly Myctophidae, Gonostomatidae, and Phosichthyidae. Beckley et al. (2019) found these patterns to correlate with changes in environmental variables.

Though numerous studies on ichthyoplankton are present from other regions in the Indian Ocean, very few studies can be found from the north-central Indian Ocean region. In waters, particularly around Sri Lanka, only a handful of research activities have been carried out concerning ichthyoplankton dynamics. The first attempt to study ichthyoplankton was by Deepananda and Arsecularatne in 2013, focusing on the distribution and abundance of finfish larvae in coastal waters off the Rekawa, located in the southern region of Sri Lanka. This study focused on the importance of Rekawa mangrove forest as a refuge for the early life stages of fish. Moreover, Rathnasuriya et al. (2021) have investigated the larval fish diversity and abundance around Sri Lankan waters based on a survey conducted in 2018.

Coastal areas of Sri Lanka are generally regarded as highly productive, especially during the southwest monsoon period (Krakstad et al., 2018; Dalpadado et al., 2021; Wimalasiri et al., 2021). The west coast of Sri Lanka with three lagoons (Bolgoda, Lunawa, and Negombo) and four estuaries (Bentota, Kalu River, Kelani River, and Maha Oya) borders a coastal population with fisheries as their main livelihood. Lagoons, estuaries, and mangrove forests are parts of coastal ecosystems having an important role in fish survival (Haryono et al., 2018), supporting vital fisheries activities in the region (Blaber et al., 2000).
In this study, the hypothesis is that lagoons and estuaries and their associated habitats such as mangroves and seagrasses in the west coast of Sri Lanka harbour high abundances of ichthyoplankton. Furthermore, this study hypothesise that these two major coastal ecosystems enrich adjacent sea areas with nutrients and provide suitable habitats for many species, thereby increasing the diversity in this area.

The present study aims to investigate the spatial and temporal variations in species diversity and abundance of ichthyoplankton in the central Indian Ocean, focusing on the west coast of Sri Lanka. This analysis provides baseline information on ichthyoplankton from the west coast of Sri Lanka, contributing to identify vital fishery resources and spawning grounds from a poorly studied area of the Indian Ocean.

\section{Materials and Methods}

\section{Study area}

The sampling stations were selected along the coastal stretch in the west coast where two major fisheries districts were located, Colombo and Negombo that accounted for 5,935 and 29,720 metric ton of marine fish catch in 2017, respectively (Fisheries Statistics, 2018). Moreover, the west coast has several lagoons and estuaries enriching adjacent coasts. The present study area borders three of the most important ecosystems, namely: Kelani River, Negombo Lagoon, and Maha Oya Estuary (Fig.1).
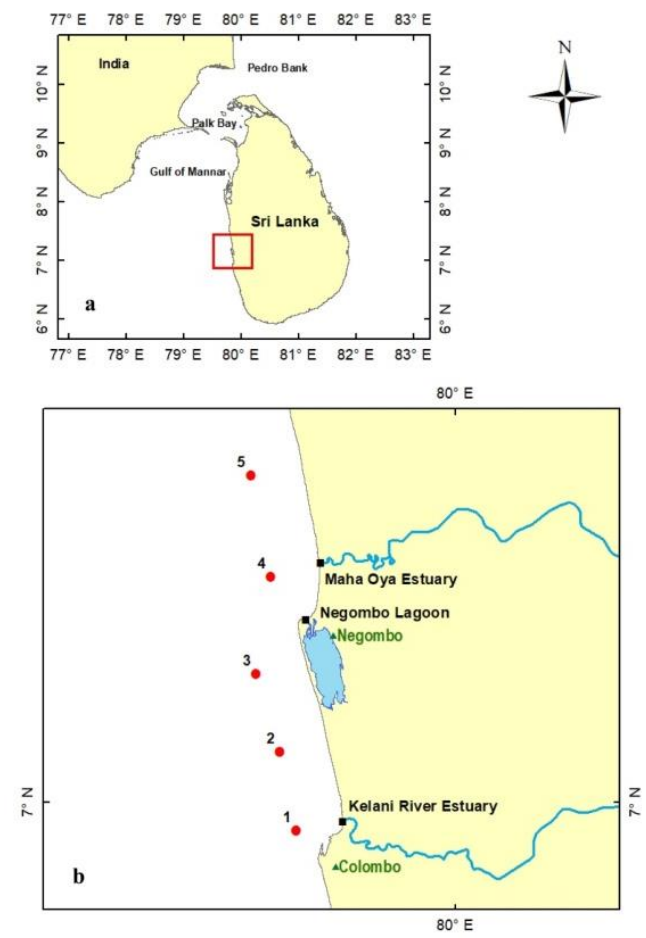

Fig. 1. Map showing the sampling area (red box) for study of ichthyoplankton on the west coast of Sri Lanka (a), red filled circles show location of sampling stations with respect to Maha Oya Estuary, Negombo Lagoon, and Kelani River Estuary (b). 
The Kelani River is one of the major river systems in Sri Lanka that eventually enters the Indian Ocean on the west coast, just a few kilometres north of Colombo. Negombo Lagoon is one of the most productive regions in Sri Lanka (Pillai, 1965). Around 133 fish species were previously reported to inhabit the Negombo Lagoon system (GCEC, 1991) and more than half of them are migratory (Anadromous, Catadromous or Amphidromous). Negombo Lagoon has historical and socio-economic values and is an important national fishing centre (Jayakody, 1994). Maha Oya, which separates the western and the north-western provinces, is one of the largest perennial rivers in Sri Lanka (Santhushya et al., 2015) that flows into the west coast, where the northernmost sampling took place.

\section{Sampling stations}

Samples were collected from five stations in two transects (Fig. 1). Stations 1, 2, and 3 were located on the first transect along the coast from Kelani River up to Negombo Lagoon, whereas stations 4 and 5 were situated on the second transect from Maha Oya estuary and northwards. These stations were located approximately $6 \mathrm{~km}$ away from the shore.

\section{Sample collection}

Samples were collected twice a month in March and September and only once a month in October and November 2018, each representing a particular monsoon season (Table 1). Ichthyoplankton sampling was conducted using a small fibreglass fishing boat ( 6 $\mathrm{m})$ with an outboard motor (40 HP). The same boat was used during the entire sampling period. No conductivity, temperature, and depth (CTD) measurements were taken as appropriate small sensors in small boats were not available. Hence, it was referenced to other corresponding studies from the region.

Table 1. Ichthyoplankton sampling information related to monsoon seasons from the west coast of Sri Lanka.

\begin{tabular}{|c|c|c|}
\hline Month & $\begin{array}{l}\text { Sample collection } \\
\text { dates }\end{array}$ & $\begin{array}{l}\text { Monsoon } \\
\text { season }\end{array}$ \\
\hline March & $\begin{array}{l}16.03 .2018 \\
29.03 .2018\end{array}$ & $\begin{array}{l}1^{\text {st }} \text { inter } \\
\text { monsoon }\end{array}$ \\
\hline September & $\begin{array}{l}14.09 .2018 \\
27.09 .2018\end{array}$ & $\begin{array}{l}\text { Southwest } \\
\text { monsoon }\end{array}$ \\
\hline October/November & $\begin{array}{l}17.10 .2018 \\
14.11 .2018\end{array}$ & $\begin{array}{l}2^{\text {nd }} \text { inter } \\
\text { monsoon }\end{array}$ \\
\hline
\end{tabular}

Horizontal and vertical samples were collected at each station using a WP2 plankton net (Tranter et al., 1968) of $180 \mu \mathrm{m}$ mesh size, $56 \mathrm{~cm}$ mouth opening and $\sim 260 \mathrm{~cm}$ length. The horizontal samples were collected by towing the net on the surface using a float at a uniform speed $\left(0.9 \mathrm{~ms}^{-1}\right)$ perpendicular to the shore for two minutes. Vertical samples were collected by hauling the net at fixed position at uniform velocity $\left(0.5 \mathrm{~ms}^{-1}\right)$ from depth of approximately $20 \mathrm{~m}$ (depending on the bathymetry). After gently washing the net from outside, the filtered sample at the cod end of the net was collected into a $180 \mu \mathrm{m}$ mesh sized filter and the plankton organism and detritus gathered were preserved using a $4 \%$ formaldehyde + seawater solution onboard. These samples were then brought to the Marine Biological Resources Division laboratory at the National Aquatic Resources Research and Development Agency (NARA), Sri Lanka, for further analysis.

\section{Sample analysis}

At the NARA laboratory, samples were filtered using a $180 \mu \mathrm{m}$ mesh to concentrate the mixture of plankton and detritus. Fish eggs and larvae were separated from this mixture initially by observing with the naked eye. The remaining larvae and eggs were separated using a stereomicroscope (3013 ACCU-SCOPE, USA). The sorted eggs and larvae were preserved once again using a $4 \%$ formaldehyde solution in separate bottles for taxonomic identification. The sorted fish eggs and larvae in vertical and horizontal samples were identified to the lowest possible taxonomic level using the standard keys by Leis and Carson-Ewart (2000) and Rodriguez et al. (2017).

\section{Egg identification}

Several anatomical and morphological features of the fish eggs were used in the taxonomic identification, such as shape, size, chorion (ornamented or unornamented), inner egg membrane, yolk, perivitelline space, and oil globules (Ahlstrom and Moser, 1980). Eggs with similar characteristics were categorised into a single group. All the above characteristics were recorded per each category of egg, along with the images. The eggs were identified to the lowest possible taxonomic level with the use of available literature. Numerous eggs from the same taxonomic level were enumerated station-wise.

\section{Larval identification}

The main characteristics used in larval fish identification are the body form, the pigmentation pattern, and meristic and morphometric characteristics following Rodriguez et al. (2017).

\section{Data analysis}

The abundance of fish eggs and larvae was calculated separately for vertical and horizontal samples by dividing the number of eggs or larvae encountered with the volume of seawater filtered. The volume of seawater was estimated from tow length and mouth opening area of the net, assuming $100 \%$ filtration efficiency. Fish egg and larvae abundance were standardised by calculating the number of eggs and larvae per $10 \mathrm{~m}^{-3}$ and then $\log$ transforming $[\log (\mathrm{x}+1)]$, 
where $\mathrm{x}$ is the abundance (Smith and Richardson, 1977; Rabbaniha et al., 2013). Data were statistically analysed by using SPSS statistics version 25 software. The normality of data was tested by the KolmogorovSmirnov test at $95 \%$ significance level (Demirel, 2015). One-way analysis of variance (ANOVA) was used to investigate the significance of spatial (sampling stations) variation (Mota et al., 2017) in the mean ichthyoplankton abundance, considering stations as the factor. The Tukey's Honestly Significant Difference (HSD) test was applied whenever significant $(P<0.05)$ differences were detected (Reynalte-Tataje et al., 2012). A t-test was used to check whether there is a significant difference in abundance between vertical and horizontal samples.

Biological indices; Shannon-Wiener diversity index (Shannon and Weaver, 1949), Simpson index (Simpson, 1949), Evenness (Pielou, 1966), Dominance (Balkate, 2017), and Richness (Margalef, 1958) were calculated for larval fish (Supplementary Table 1). These indices were modified for the families as it was the lowest possible taxonomic level identification. Furthermore, the relative abundance of identified families was also calculated by dividing the total number of individuals identified per each family by the total number of individuals identified. All the identified larval families were ranked in the ascending order of their relative abundance.

\section{Results}

\section{Egg abundance}

The highest abundances of eggs were recorded in March for both vertical and horizontally towed samples (Figs. 2a, b). The lowest abundances were recorded in October, with station 1 having extremely low values $\left(<10\right.$ eggs $\left.10 \mathrm{~m}^{-3}\right)$. When considering the vertical and horizontal samples the highest abundance of 535 eggs $10 \mathrm{~m}^{-3}$ was recorded from a single station (station 3) in March.

\section{Larval fish abundance}

No systematic pattern in temporal distribution was found for the larval abundance during the 4 months, for both vertical and horizontal samples. However, stations 4 and 5 showed comparatively higher abundances (Figs. 2c, d). The highest larval abundance was recorded in station 4 in horizontal samples with an abundance of 35 and 37 larvae $10 \mathrm{~m}^{-3}$ in March and October, respectively.

The mean larval abundance for horizontal samples (11 larvae $10 \mathrm{~m}^{-3}$ ) was higher than that of vertical samples (6 larvae $10 \mathrm{~m}^{-3}$ ). As expected, the egg abundances were much higher than larval abundances in both vertical and horizontal towed samples (Fig. 2).
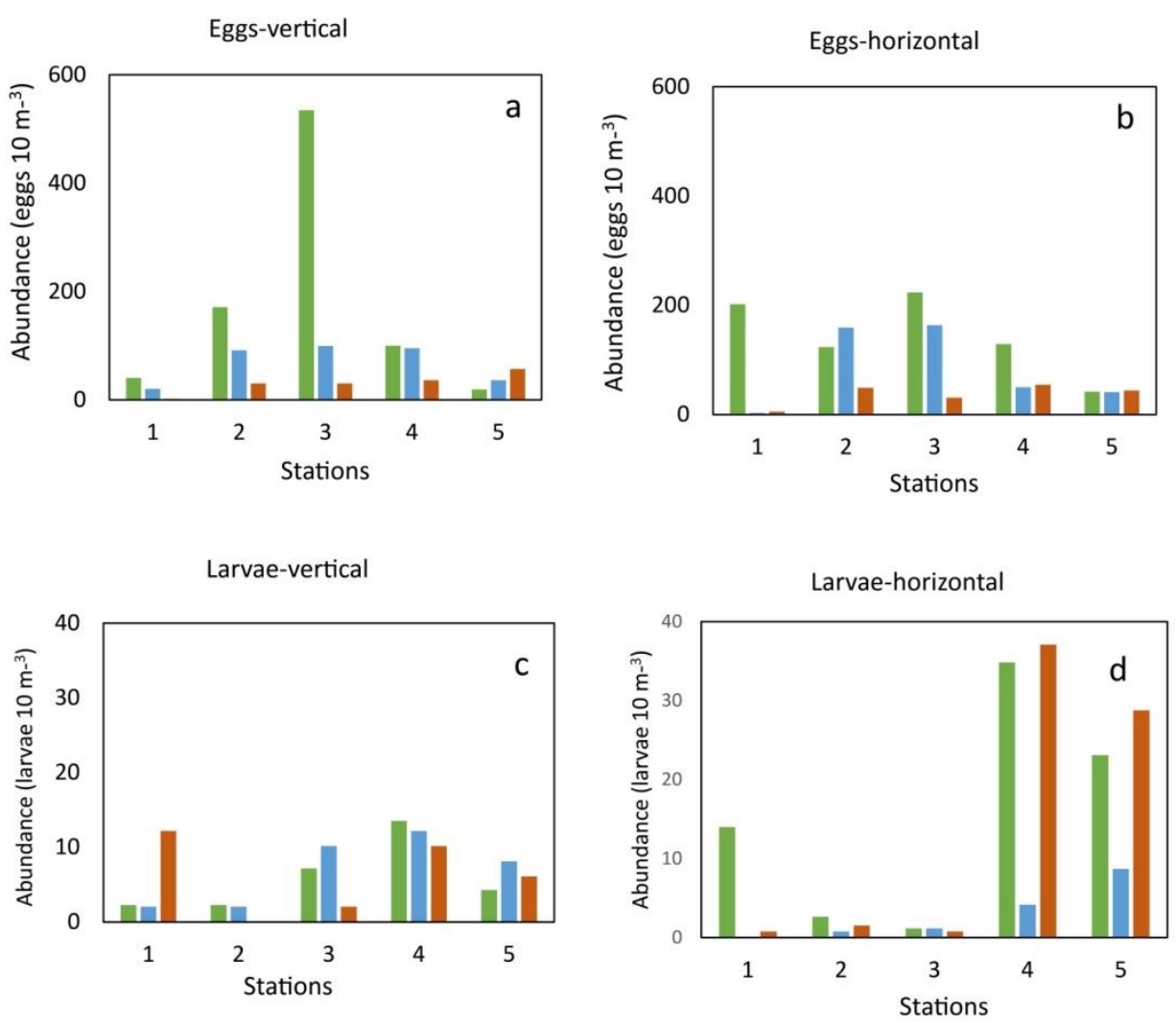

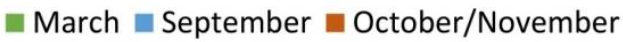

Fig. 2. Ichthyoplankton abundance at different stations in March, September, and October/November 2018 from the west coast of Sri Lanka: (a) Fish eggs-vertical hauls, (b) Fish eggs-horizontal hauls, (c) Larval fish-vertical hauls and (d) Larval fishhorizontal hauls. Note that the scale on the y-axis is different. 
The t-tests performed showed no significant differences in abundance between vertical $(P=0.94)$ and horizontal $(P=0.26$ ) hauls (Tables $2 a, b)$. However, as the samples were collected in somewhat different water masses when using vertical (deeper) than horizontal (surface) tows, the results from these two sampling methods are presented separately.

The box plot illustrates that although the catches showed no significant difference between the two methods, the mean larval abundance was twice as high in horizontal hauls compared to vertical ones (Fig. 3; Table 2b). Furthermore, the sampling variance in larval abundance was much higher in the horizontal compared to the vertical ones.

\section{Spatial variation in abundance}

Results of One-way ANOVA (Table 3) indicate that there were no significant differences $(P>0.05)$ between the mean egg abundances among the five stations in vertical or horizontal samples. However, significant differences $(P<0.05)$ between the larval station-wise abundance were seen for vertical and horizontal samples (Table 3). In the vertical samples of larvae, significant differences were found between stations 2 and 4 according to the HSD test $(P<0.05)$. In horizontal samples, stations 3 and 4 and stations 3 and 5 were significantly different $(P<0.05)$. In the horizontal hauls, the northern stations 4 and 5 generally had higher larval abundance than the rest of the stations (see Fig. 2d).

\section{Taxonomic composition of ichthyoplankton}

The taxonomic identification of fish eggs and larvae is a much more difficult task than identifying the juvenile and adult stages of fish. Generally, fish eggs are spherical, transparent, and of similar size, hence, morphological identification is difficult, except for those having unique shapes, ornamented chorions, or other features.

A total of 4095 fish eggs and 465 larval fish were collected from the study area. Of these, 285 larval fish were identified to the order or family level, while a much lower number of fish eggs could be identified. Larvae identified in this study belonged to 23 families (Table 4), while the identifiable eggs belonged only to three major families.

Among the 23 larval fish families, 19 were of commercial importance. Fourteen families were important as food fish: Carangidae, Clupeidae, Engraulidae, Gerreidae, Leiognathidae, Lutjanidae, Mugilidae, Mullidae, Serranidae, Siganidae, Sillaginidae, Sparidae, Cynoglossidae, and Paralichthyidae. The latter two families (Cynoglossidae, and Paralichthyidae) have somewhat minor interest as food fish. Furthermore, five families with importance in the ornamental fish industry were also identified, namely Blenniidae, Callionymidae, Gobiidae, Percophidae, and Synodontidae. Out of the 23 families, 14 demersal, 2 pelagic, 2 reef-associated, 4 pelagic/demersal/reefassociated, and 1 bathydemersal (Percophidae) were recorded. Families such as Lutjanidae, Serranidae, and Siganidae comprised both demersal and reefassociated fish. Furthermore, larvae of the family Carangidae comprising both pelagic and demersal species were encountered (Table 4). Results from this study indicate higher demersal fish diversity compared to the pelagic.

Overall, 180 of the larval fish specimens could not be identified due to structural damage or in an early or indeterminate stage of development. Most of the larvae in the yolk sac stage could not be identified,

Table 2. Results of the t-tests for vertical and horizontal samples of fish eggs (a) and larvae (b) from the west coast of Sri Lanka. The abundance of fish eggs and larvae is expressed as number $\mathrm{m}^{-3}$.

\begin{tabular}{lll} 
& & \\
\hline & Egg-vertical & Egg-horizontal \\
\hline Mean & 9.10 & 8.80 \\
Variance & 170.42 & 51.99 \\
Observations & 15.00 & 15.00 \\
Hypothesised mean & 0.00 & \\
difference & & \\
Degrees of freedom & 22.00 & \\
t Stat & 0.08 & \\
$\mathrm{P}(T<=$ t) two-tail & 0.94 & \\
\hline
\end{tabular}

\begin{tabular}{lll}
\hline & & \\
\hline Mean & Larvae-vertical & Larvae-horizontal \\
Variance & 0.63 & 1.06 \\
Observations & 0.20 & 1.83 \\
Hypothesised mean & 15.00 & 15.00 \\
difference & 0.00 & \\
Degrees of freedom & 17.00 & \\
t Stat & -1.18 & \\
$P(T<=$ t) two-tail & 0.26 & \\
\hline
\end{tabular}

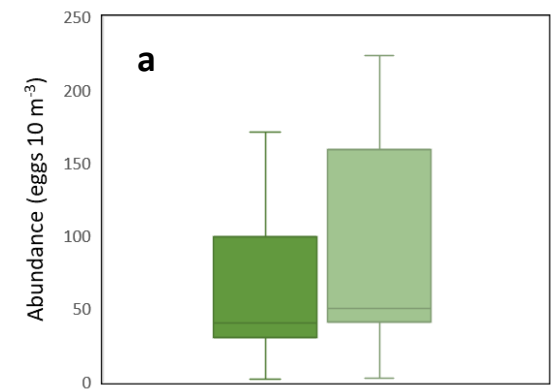

$\square$ Vertical $\square$ Horizontal

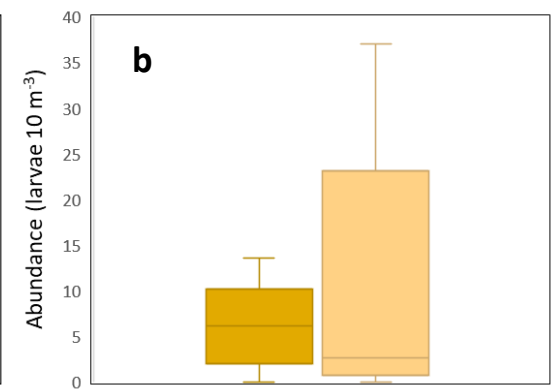

$\square$ Vertical $\square$ Horizontal
Fig. 3. Box plots showing abundance in vertical and horizontal hauls for (a) fish eggs and (b) larval fish from the west coast of Sri Lanka. The boxes are divided by the median value and framed by the upper and lower quartile. The whiskers extend to the highest and lowest observations in each direction. 
Table 3. Summary of One-way ANOVA of mean egg and larval abundance for vertical and horizontal samples from the west coast of Sri Lanka. Statistically significant values are in bold and df = 4 (between groups), $d f=10$ (within groups) and df = 14 (total).

\begin{tabular}{llll}
\hline Sample type & $\begin{array}{l}\text { Mean square } \\
\text { (Between groups) }\end{array}$ & Fvalue & Pvalue \\
\hline Eggs - vertical & 0.404 & 2.055 & 0.162 \\
Eggs - horizontal & 0.329 & 1.344 & 0.320 \\
Larvae - vertical & 0.239 & 3.775 & 0.040 \\
Larvae- horizontal & 0.723 & 4.998 & 0.018 \\
\hline
\end{tabular}

Table 4. Station-wise composition of larval fish families from the west coast of Sri Lanka. Relative abundance (Percentage contribution of the total) and ranking based on highest to lowest relative abundance values.

\begin{tabular}{|c|c|c|c|c|c|c|c|c|}
\hline \multirow{2}{*}{ Family } & \multicolumn{5}{|c|}{ Station } & \multirow{2}{*}{ Total } & \multirow{2}{*}{ Relative abundance } & \multirow{2}{*}{ Rank } \\
\hline & 1 & 2 & 3 & 4 & 5 & & & \\
\hline Ambassidae* & & & 1 & 3 & & 4 & 1.95 & 10 \\
\hline Blenniidae* & 2 & 4 & & 35 & 16 & 57 & 27.80 & 2 \\
\hline Callionymidae* & & 1 & & 1 & 1 & 3 & 1.46 & 11 \\
\hline Carangidae $^{*+}$ & & & & 1 & & 1 & 0.49 & 16 \\
\hline Clupeidae $^{+}$ & & & & 1 & 13 & 14 & 6.83 & 3 \\
\hline Cynoglossidae* & 1 & & & 1 & & 2 & 0.98 & 13 \\
\hline Engraulidae $^{+}$ & & & & 1 & 8 & 9 & 4.39 & 5 \\
\hline Gerreidae* & & & & & 1 & 1 & 0.49 & 16 \\
\hline Gobiidae* & & 2 & 3 & 4 & 2 & 11 & 5.37 & 4 \\
\hline Leiognathidae* $^{*}$ & & & & 1 & & 1 & 0.49 & 16 \\
\hline Lutjanidae & & & & 2 & & 2 & 0.98 & 13 \\
\hline Mugilidae* & & & & 1 & & 1 & 0.49 & 16 \\
\hline Mullidae* & & & & 7 & & 7 & 3.41 & 7 \\
\hline Paralichthyidae* & & & 1 & & & 1 & 0.49 & 16 \\
\hline Percophidae & & & 3 & 1 & 1 & 5 & 2.44 & 9 \\
\hline Platycephalidae* & & 2 & 1 & 3 & 1 & 7 & 3.41 & 7 \\
\hline Pomacanthidae & & & & 1 & & 1 & 0.49 & 16 \\
\hline Pseudochromidae & 1 & & & & & 1 & 0.49 & 16 \\
\hline Serranidae & 1 & & & 1 & & 2 & 0.98 & 13 \\
\hline Siganidae & & 1 & 1 & 53 & 7 & 62 & 30.24 & 1 \\
\hline Sillaginidae* & & & & 2 & 1 & 3 & 1.46 & 11 \\
\hline Sparidae* & 1 & & 1 & 6 & 1 & 9 & 4.39 & 5 \\
\hline Synodontidae* & 1 & & & & & 1 & 0.49 & 16 \\
\hline
\end{tabular}

*Demersal, + Pelagic

likely due to their fragile nature where they get easily damaged by handling etc.

The top 10 most abundant larval fish families out of the 23 identified are shown in Figure 4. The family Siganidae had the highest abundance, contributing to $30 \%$ of the identified specimens, followed by Blenniidae $(28 \%)$, Clupeidae (7\%), Gobiidae (5\%), and Engraulidae (4\%).

Overall, 80 larval fish were recorded in the order Clupeiformes. The order Clupeiformes consisted of four families, namely, Clupeidae, Engraulidae, Chirocentridae, and Pristigasteridae. Clupeiformes larvae have few common characteristics such as elongated body; long, straight, partially straight gut;

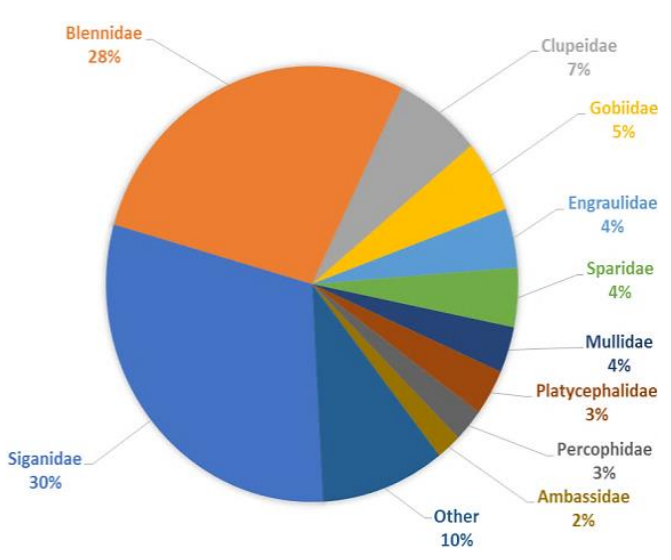

Fig. 4. Top 10 most abundant larval fish families and their percentages in samples from the west coast of Sri Lanka. 
posteriorly placed fins (Leis and Carson, 2000). Hence, the initial larval stages in this order could not be identified to the family level as the distinguishing morphometric or meristic characteristics were not fully developed. Therefore, they were placed under the higher taxonomic level, 'Order' in this study to avoid erroneous classification. In addition, three families of fish eggs were identified: Engraulidae, Cynoglossidae and Clupeidae.

\section{Biological diversity of larval fish families}

Diversity was calculated only for the larval fish families, as only three fish egg families were identified during this study. These indices have been calculated using pooled vertical and horizontal hauls and samples from all 4 months collected at each station. Table 5 summarises the diversity indices, richness, dominance, and evenness calculated for larval fish recorded in all five stations.

As shown in Table 5, the highest number of families (19), as well as the highest richness (8.58), was recorded in station 4. Station 1,3 and 5 also had higher and similar richness than station 2, which accounts for the lowest richness (4). The highest Shannon-Weiner diversity index (1.85) was observed in station 5. Station 4, which had the highest number of families and richness has the lowest Shannon-Weiner diversity index (0.8). This is mainly due to the low evenness (0.27) observed in station 4 as only a few major families dominate this site. The ShannonWeiner diversity index depends on both richness and evenness (Strong, 2016). However, station 4 had the highest Simpson index (0.27) among all stations. This results from the Simpson index being a dominance index, giving more weight to common or dominant families.

\section{Discussion}

\section{Ichthyoplankton abundance}

Lagoons and estuaries and their associated habitats such as mangroves and seagrasses provide safe refuges as nurseries and feeding grounds for many commercially important species such as shellfish and finfish (Miththapala, 2013). Many fish species have adapted to spawn in marine coastal waters, while larval and juvenile stages migrate into estuaries or lagoons to feed and grow in their shelter (Miththapala, 2013). Recent studies also confirm that the cooler, nutrient rich southwest coast of Sri Lanka is a highly productive (phytoplankton and zooplankton) area (Krakstad et al., 2018; Dalpadado et al., 2021; Wimalasiri et al., 2021). These investigations, overlapping with our study period, show that the west coast of Sri Lanka has a lower sea surface temperature $\left(\sim 27{ }^{\circ} \mathrm{C}\right)$ and higher salinity $(\sim 35)$ than that of the east coast $\left(29.5^{\circ} \mathrm{C} ; 33.8\right)$. Besides, these studies show that the west coast has a higher chlorophyll concentration $\left(\sim 1 \mathrm{mg} \cdot \mathrm{m}^{-3}\right)$ than the east coast $\left(0.1-0.5 \mathrm{mg} \cdot \mathrm{m}^{-3}\right)$, depicting high productivity in the west coast during the southwest monsoon period.

The mean larval abundance of the present study (10 larvae $10 \mathrm{~m}^{-3}$ ) was higher than that of the ichthyoplankton survey conducted in the Rekawa Lagoon ( 220 km away from sampling site), in the south coast (46.6 larvae $100 \mathrm{~m}^{-3}$ ) during September 2011 to February 2012 (Deepananda and Arsecularatne, 2013). In the current study, egg abundance was found to be highest in March, which is the pre-monsoon season. In a similar study conducted in the Gulf of Mannar ( $185 \mathrm{~km}$ north of the study area), similar results were observed, where the number of eggs increased from January until they reached the peak in March (Bapat, 1955). Bapat observed relatively low number of eggs, with a slight increase during September-November, corroborating with results from the present study. In the present study, station 4 had the highest mean larval abundance for both horizontal and vertical samples. Station 4 is located central to the Negombo Lagoon mouth and Maha Oya Estuary. Negombo Lagoon is one of the most productive lagoons in Sri Lanka, consisting of a dynamic mangrove ecosystem (Silva et al., 2016). In addition, Maha Oya is one of the largest perennial rivers in Sri Lanka (Santhushya et al., 2015), bringing nutrient-rich waters. High abundance in this region could be due to good feeding conditions for larval fish.

No systematic spatial distribution pattern was found for the larval abundance during the 3-month period for vertical and horizontal samples. However, the samples from stations 4 and 5 had a comparatively

Table 5. Summary of the diversity indices calculated for 5 stations from the west coast of Sri Lanka. See Supplementary Table 1 for more details.

\begin{tabular}{llllll}
\hline Index & Station 1 & Station 2 & Station 3 & Station 4 & Station 5 \\
\hline No. of families & 6 & 5 & 7 & 19 & 11 \\
Shannon-Weiner (H) & 1.75 & 1.47 & 1.80 & 0.80 & 1.85 \\
Simpson (D) & 0.05 & 0.18 & 0.11 & 0.26 & 0.19 \\
Evenness (J) & 0.98 & 0.91 & 0.93 & 0.27 & 0.77 \\
Dominance & 0.02 & 0.09 & 0.08 & 0.73 & 0.23 \\
Richness & 5.92 & 4.00 & 5.76 & 8.58 & 5.83 \\
\hline
\end{tabular}


higher abundance, likely due to high productivity in this region. Station 1 had the lowest ichthyoplankton abundances, probably due to the closer proximity to the Kelani River mouth (see Fig. 1), where the tidal fluctuation and changes in salinity could make it difficult for the eggs and larval fish to prevail in the area. The eggs and larval fish are likely dispersed to the adjacent areas with prevailing localised currents (Krakstad et al., 2018; Rathnasuriya et al., 2021) where low disturbance occurs.

The spatial and temporal distribution of fish eggs and larvae are controlled by both active behaviour and passive transport mechanisms. These mechanisms result from a combination of biotic and abiotic factors, as described earlier. According to the results of the present study, the highest mean egg abundance was observed in station 3, whereas the highest mean larval abundance was reported in station 4. Several factors may affect this scenario. The abundance and distribution of larval fish depend on favourable biological conditions. The fish spawning time and location must ensure proper and sufficient food, minimum risk from predators, and appropriate environmental conditions (Rabbaniha, 2013). Furthermore, suitable spawning habitats for fish require the accomplishment of the "fundamental triad hypothesis" explained by Bakun (1996): i) nutrient enrichment processes, ii) concentration of food particles, and iii) retention of eggs and larvae within a favourable habitat. Station 4 fulfils most of the above requirements for the survival of early fish larval stages, although station 3 might be a suitable spawning location. The low abundance of ichthyoplankton in station 1, located near the Kelani River mouth, may be due to low salinity and large discharges preventing retention within this area. A study by Wargo et al. (2009) showed significantly lower ichthyoplankton abundances close to the river plume with low salinities compared to salt concentrations further away. Factors such as currents, tides, wind, and retention mechanisms may cause the transport of fish eggs and larval fish from the spawning ground to the nursery area (Arnold, 1974). Future studies should focus more on mechanisms behind the spatial and temporal distribution variations of ichthyoplankton in these waters, such as biophysical factors.

\section{Diversity}

The present study recorded higher demersal fish diversity in comparison with the pelagic diversity. Previous records also show that the demersal catches are highly diverse in terms of the number of species (De Bruin et al., 1995). A survey conducted by the R/V "Dr Fridtjof Nansen" in 2018 showed that the southwest coast had the second highest biomass, and the number of families in the bottom trawl catches compared to other regions of Sri Lanka (Krakstad et al., 2018). Besides, survey results from 2018 showed that though the pelagic catches were the highest in the southwest, the biomass was lower than that of the demersal fish.

The family Siganidae had the highest abundance, contributing to $30 \%$ of the identified specimens in the present study. Siganids or rabbitfish are small to moderate size, mainly herbivorous benthic fish found in an array of habitats, including coral reefs, seagrass beds and estuaries. Some species have commercial value as food fish and some are important in aquaculture (Leis and Carson-Ewart, 2000). Among the 27 siganid species, 9 are found in Sri Lankan waters (Leis and Carson-Ewart, 2000; Terny and Kasun, 2012). Blenniidae, which accounted for $28 \%$ in the present study, is a large and diverse group of small, benthic, scaleless fish (Leis and Carson-Ewart, 2000), where 33 species have been recorded in Sri Lanka (Terny and Kasun, 2012).

The order Clupeiformes has enormous commercial importance in Sri Lankan waters. There are four families in this order (Clupeidae, Engraulidae, Chirocentridae, and Pristigasteridae), all of which occur in the Indo-Pacific region where over 350 species have been recorded (Leis and Carson-Ewart, 2000). Family Clupeidae, which includes herrings, sardines and anchovies accounted for $7 \%$ in the present study. Sardines and other small pelagic fish species contribute to about $40 \%$ of the total fish catch in Sri Lanka (Dayaratne, 1985). On the west coast of Sri Lanka, the fishery is based on smallmeshed gillnets. Three species of clupeids; Amblygaster sirm (Walbaum, 1792), Sardinella gibbosa (Bleeker, 1849) and Sardinella albella (Valenciennes, 1847) contribute to about 70 to $80 \%$ of these small pelagic fish catches (Dayaratne, 1985).

Five percent of identified fish was Gobiidae which constitutes the largest family of marine fishes. Moreover, the smallest fishes generally belong to this family (Froese and Pauly, 2019). According to Terny and Kasun (2012), 64 species have been recorded in Sri Lankan waters. They are mostly found in shallow coastal waters and around coral reefs. Many are popular as aquarium fish (Froese and Pauly, 2019), hence, an economically important family in this region.

In an ichthyoplankton survey in the coastal waters in the southern province (off Rekawa), 12 families were recorded, with the most abundant families being Blenniidae, Gerreidae, Mullidae, Carangidae and Clupeidae (Deepananda and Arsecularatne, 2013). Moreover, in the ecosystem survey by R/V "Dr Fridtjof Nansen" in 2018, larval fish species diversity and composition in the Indian Ocean were mapped for the first time using combined morphological and molecular methods (Rathnasuriya et al., 2021). They studied larval diversity in six coastal regions (North East, Central East, South East, South, South West, and North West) off Sri Lanka using Multinet Mammoth (1 $\mathrm{m}^{2}, 300 \mu \mathrm{m}$ single net). In their study, 80 
different species belonging to 69 families were identified with Carangidae as the most numerous and abundant family, followed by Myctophidae, Lutjanidae, Scombridae, and Caesionidae. Out of the 23 families identified in the present study, demersal fish families dominated, accounting for $\sim 60 \%$ of the total (Siganidae, Blenniidae, Sparidae, Mullidae and others), whereas pelagic comprised only $\sim 9 \%$ (Clupeidae and Engraulidae). Other families such as Carangidae consisted of species belonging to pelagic, demersal or species inhabited in reef associated environments. The gears used for sampling larval fish differed among the above studies, also the period and area, hence, these results are not directly comparable. The WP2 net, a ring used in the current study, recorded 23 families from the west coast. This simple ring net was easier to operate in the smaller vessels available for this study. Nevertheless, families such as Clupeidae, Blenniidae, and Gobiidae are dominant families in most studies.

\section{Is the west coast a suitable nursery ground for larval fish?}

In general, the west coast is more productive than the east coast (Yapa 2012; Dalpadado et al., 2021; Wimalasiri et al., 2021). West regions are most productive ( $\mathrm{Chl}$ a $>1 \mathrm{mg}^{-3} \mathrm{~m}^{-3}$ ) from May to October, coinciding with the southwest monsoon period (Yapa, 2012). The spawning of fish is generally concentrated in nearshore gyres, likely facilitating the return of larvae to the productive coastal areas which act as nursery grounds (Johannes, 1978; Da Silva et al., 2018). Ichthyoplankton results from the present study corroborate that spawning likely occurs close to the productive coastal regions. The abundance and diversity, particularly of demersal larval fish, confirm the importance of the west coast of Sri Lanka as an important nursery ground for fish. Moreover, the west coast continental shelf is generally rocky comprising coral reefs, creating a favourable demersal environment. In addition, the estuarine mouth with a muddy, sandy bottom harbours some demersal fish species (De Bruin et al., 1995).

\section{Conclusion}

The high diversity and abundance of fish eggs and larvae recorded in this study indicate that the west coast of Sri Lanka is an important spawning and nursery ground for fish. The southwest monsoon seems to be an important trigger for the spawning activities in this region. The high abundance and diversity, particularly of demersal larval fish confirm the importance of the west coast of Sri Lanka as an area with preferred spawning habitats and vital nursery grounds for these fishes. The current ichthyoplankton study establishes baseline information on ecologically and economically important families on the west coast of Sri Lanka. This background information is essential for planning future annual ecosystem surveys in an understudied region of the north-central Indian Ocean. Future surveys should collect ichthyoplankton samples for molecular sequencing to obtain more accurate identification to species level. DNA barcoding of fish eggs is vital for establishing potential spawning grounds. At the same time, there is a need to elucidate the role of biophysical variables is key to understanding the distribution patterns of ichthyoplankton in this region.

\section{Acknowledgements}

The first author thanks the National Aquatic Resources Research and Development Agency (NARA) for giving her the opportunity to engage in this research. The financial and other support provided by the NARA is highly appreciated. Special thanks are also extended to the staff of the Marine Biological Research Division of NARA, for their help given in the laboratory analysis. Moreover, the contribution of $\mathrm{Mr}$. S.J.W.W.M.M.P. Weerasekara of Marine Biological Research Division and Mr. S.S. Gunasekara of National Institute of Oceanography and Marine Affairs, at NARA in the sample collection is highly appreciated. We are grateful to the bilateral project between Sri Lanka and Norway (Technical assistance to improve management of the fish resources of Sri Lanka. LKA3183, LKA-16/0005) for supporting this research.

Conflict of interest: The authors declare that they have no conflict of interest.

\section{References}

Aceves-Medina, G., Jiménez-Rosenberg, S.P.A., Hinojosa-Medina, A., Funes-Rodríguez, R., Ricardo, J.S., Lluch-Belda, D., Smith, P.E., Watson, W. 2003. Fish larvae from the Gulf of California. Scientia Marina 67:1-11. https://doi.org/10.3989/scimar.2003.67n11

Ahlstrom, E.H., Moser, H.G. 1980. Characters useful in identification of pelagic marine fish eggs. California Cooperative Oceanic Fisheries Investigations Reports 21:121-131.

Arnold, G.P. 1974. Rheotropism in fishes. Biological Reviews 49:515-576. https://doi.org/10.1111/j.1469-185X.1974.tb01173.x

Auth, T.D., Daly, E.A., Brodeur, R.D., Fisher, J.L. 2018. Phenological and distributional shifts in ichthyoplankton associated with recent warming in the northeast Pacific Ocean. Global Change Biology 24:259-272. https://doi.org/10.1111/gcb.13872

Bakun, A. 1996. Patterns in the ocean: ocean processes and marine population dynamics. California Sea Grant, in cooperation with Centro de Investigaciones Biologicas del Noroeste, La Paz, Mexico. 323 pp.

Balkate, J.J. 2017. Identification of finfish seed and its seasonal variation along the Kasarveli Estuary of Ratnagiri Coast of Maharashtra. Ph.D. Thesis, College of Fisheries, Shirgaon, Ratnagiri, India. $127 \mathrm{pp}$.

Bapat, S.V. 1955. A preliminary study of the pelagic fish eggs and larvae of the Gulf of Mannar and the Palk Bay. Indian Journal of Fisheries 2:231-255.

Beckley, L.E., Holliday, D., Sutton, A.L., Weller, E., Olivar, M.P., Thompson, P.A. 2019. Structuring of larval fish assemblages along a coastal-oceanic gradient in the macro-tidal, tropical Eastern Indian Ocean. Deep Sea Research Part II: Topical Studies in Oceanography 
161:105-119. https://doi.org/10.1016/j.dsr2.2018.03.008

Blaber, S.J.M, Cyrus, D.P., Albaret, J.J., Ching, C.V., Day, J.W., Elliott, M., Fonseca, M.S., Hoss, D.E., Orensanz, J., Potter, I.C., Silvert, W. 2000. Effects of fishing on the structure and functioning of estuarine and nearshore ecosystems. ICES Journal of Marine Science 57:590-602. https://doi.org/10.1006/jmsc.2000.0723

Dalpadado, P., Arrigo, K.A., Dijken, G.L. Gunasekara, S.S., Ostrowski, M., Bianchi, G., Sperfeld, E. 2021. Warming of the Indian Ocean and its impact on temporal and spatial dynamics of primary production. Progress in Oceanography 198:102688. https://doi.org/10.1016 /j.pocean.2021.102688

Da Silva, V.E.L., Teixeira, E., Batista, V.S., Fabré, N.N. 2018. Spatial distribution of juvenile fish species in nursery grounds of a tropical coastal area of the south-western Atlantic. Acta Ichthyologica Et Piscatoria 48:9-18. https://doi.org/10.3750/AIEP/02299

Dayaratne, P. 1985. Status of the sardine stocks on the west coast of Sri Lanka. Journal of National Aquatic Resources Agency, Sri Lanka 32:147-150.

De Bruin, G.H., Russell, B.C., Bogusch, A. 1995. FAO species identification field guide for fishery purposes. The marine fishery resources of Sri Lanka, FAO, Rome, Italy. 400 pp.

Deepananda, K.H.M.A., Arsecularatne, H.S. 2013. Distribution and abundance of finfish larvae in coastal waters off the Rekawa, Sri Lanka. Journal of Environment 2:79-84.

Demirel, N. 2015. Ichthyoplankton dynamics in a highly urbanized estuary. Marine Biology Research 11:677-688. https://doi.org/10.1080 $/ 17451000.2015 .1007873$

Fisheries Statistics. 2018. Ministry of Fisheries and Aquatic Resources Development and Rural Economy. Maligawatta, Colombo 10. 24 pp.

Froese, R., Pauly, D. 2019. FishBase. World Wide Web electronic publication. www.fishbase.org, version (12/2019).

GCEC. 1991. Masterplan of Muthurajawela and Negombo Lagoon. Greater Colombo Economic Commission and Euroconsult, Colombo. $119 \mathrm{pp}$.

George, K.C. 1989. Results of ichthyoplankton surveys along the southwest coast of India with special reference to pelagic fish resources. Journal of the Marine Biological Association of India 31:172-189.

Haryono, F.E.D., Dewi, R., Pramono, T.B., Sumantri, R.A., Cahyo, T.N., Wisudyanti, D. 2018. Interaction of oceanography patterns towards the abundance of phytoplankton, zooplankton and ichthyoplankton in Teluk Penyu waters of Cilacap. E3S Web of Conferences 47:05002. https://doi.org/10.1051/e3sconf/20184705002

Jayakody, D.S. 1994. Traditional lagoon fisheries in Negombo. In: Report and proceedings. Sri Lanka/FAO national workshop on development of community based fishery, Colombo, pp. 98-103.

Johannes, R.E. 1978. Reproductive strategies of coastal marine fishes in the tropics. Environmental Biology of Fishes 3:65-84. https://doi.org/10.1007/BF00006309

Krakstad, J.O., Jayasinghe, P., Totland, A., Dalpadado, P., Søiland, H., Cervantes, D., Gunasekara, S., Liyanage, U., Haputhantri, S., Arulananthan, K., Rathnasuriya, I., Wimalasiri, U., Weerakoon, A., Nirbadha, S., Harischandra, A., Wanigatunga, R. 2018. Survey of regional resources and ecosystems of the Bay of Bengal: Part 1 Sri Lanka, 24 June-16 July 2018. NORAD-FAO programme GCP/GLO/690/NOR, Cruise reports Dr. Fridtjof Nansen, EAFNansen/CR/2018/8. 162 pp.

Leis, J.M., Carson-Ewart, B.M. 2000. The larvae of Indo-Pacific coastal fishes: an identification guide to marine fish larvae, vol. 2, Brill, USA, pp. 10-500.

Lirdwitayaprasit, P., Nuangsang, C., Puewkhao, P., Rahman, M.J., Oo, A.H., Sein, A.W. 2008. Composition, abundance, and distribution of fish larvae in the Bay of Bengal. SEAFDEC, Thailand, pp. 93-124.

Lo, N.C.H., Hunter, J.R., Charter, R. 2001. Use of a continuous egg sampler for ichthyoplankton surveys: application to the estimation of daily egg production of Pacific sardine (Sardinops sagax) off California. Fishery Bulletin 99:554-571.

Margalef, R. 1958. Information theory in ecology. General Systems 3:3671.

Miththapala, S. 2013. Lagoons and estuaries. Coastal Ecosystems Series, vol. 4. IUCN Sri Lanka Country Office, Colombo. 73 pp.

Mota, E.M.T., Garcia, T.M., Freitas, J.E.P., Soares, M.O. 2017. Composition and cross-shelf distribution of ichthyoplankton in the tropical southwestern Atlantic. Regional Studies in Marine Science 14:27-33. https://doi.org/10.1016/j.rsma.2017.05.001

Örek, Y., Mavruk, S. 2016. Ichthyoplankton of the Mediterranean Sea. In: Marine biodiversity, fisheries, and governance. The Turkish part of the Mediterranean Sea, Turan, C., Salihoğlu, B., Özgü,r Özbek E., Öztürk, B. (Eds.), Turkish Marine Research Foundation, Istanbul, Turkey, pp. 226-247.

Pielou, E.C. 1966. The measurement of diversity in different types of biological collections. Journal of Theoretical Biology 13:131-144. https://doi.org/10.1016/0022-5193(66)90013-0

Pillai, T.G. 1965. Brackish water fishery resources. Bulletin of Fisheries Research Station, Ceylon 18(2):1-11.

Rabbaniha, M., Ghasemzadeh, J., Owfi, F. 2013. Spatial and temporal patterns of fish larvae assemblage in the northern coastal waters of Persian Gulf along the Bushehr province shoreline. Journal of Fisheries Sciences 7:141. https://doi.org/10.3153/jfscom.2013015

Rathnasuriya, M.I.G., Mateos-Rivera, A., Skern-Mauritzen, R., Wimalasiri, H.B.U., Jayasinghe, R. P. P. K., Krakstad, J. O., Dalpadado, P. 2021. Composition and diversity of larval fish in the Indian Ocean using morphological and molecular methods. Marine Biodiversity 51:39 https://doi.org/10.1007/s12526-021-01169-w

Reynalte-Tataje, D.A., Agostinho, A.A., Bialetzki, A., Hermes-Silva, S., Fernandes, R., Zaniboni-Filho, E. 2012. Spatial and temporal variation of the ichthyoplankton in a subtropical river in Brazil. Environmental Biology of Fishes 94:403-419. https://doi.org/10.1007/s10641-0119955-3

Rodriguez, J.M., Alemany, F., Garcia, A. 2017. A guide to the eggs and larvae of 100 common Western Mediterranean sea bony fish species. FAO, Rome, Italy. $256 \mathrm{pp}$.

Sala, E., Aburto-Oropeza, O., Paredes, G., Parra, I., Barrera, J.C., Dayton, P.K. 2002. A general model for designing networks of marine reserves. Science 298:1991-1993. https://doi.org/10.1126 /science. 1075284

Santhushya, H.P.N., Silva, S., Wijekoon, D. 2015. Pollution driven by urbanization, pressures the odonate distribution in Maha Oya, Sri Lanka. In: Symposium proceedings, fourth international symposium on water quality and human health challenges ahead, PGIS, Peradeniya, Sri Lanka, pp. 20.

Selvam, J., Varadharajan, D., Babu, A., Balasubramanian, T. 2013. Distribution and abundance of finfish eggs from muthupettai, south east coast of India. Fisheries and Aquaculture Journal 5:166. https://doi.org/10.4172/2157-7617.1000166

Shannon, C.E. and Weaver, W., 1949. The mathematical theory of information. University of Illinois Press, Urbana. $97 \mathrm{pp}$.

Shuai, F., Li, X., Li, Y., Li, J., Yang, J., Lek, S. 2016. Temporal patterns of larval fish occurrence in a large subtropical river. PlosOne 11:e0146441. https://doi.org/10.1371/journal.pone.0146441

Silva, E.N.S., Liyanage, N.P.P. and Jayamanne, S.C. 2016. Possible effects of climate change driven sea level rise on small islet complex of Negombo Lagoon sea entrance with respect to mangrove floral community and fisheries. Proceedings of $6^{\text {th }}$ research symposium of 
Uva Wellassa University. 131 pp.

Simpson, E.H. 1949. Measurement of diversity. Nature 163:688. https://doi.org/10.1038/163688a0

Smith, P.E., Richardson, S.L. 1977. Standard techniques for pelagic fish egg and larval surveys. FAO Fisheries Technical Paper 175. 100 pp.

Strong, W.L. 2016. Biased richness and evenness relationships within Shannon-Wiener index values. Ecological Indicators 67:703-713. https://doi.org/10.1016/j.ecolind.2016.03.043

Terny, P.K.P.B., Kasun, R.D. 2012. Provisional checklist of marine fishes of Sri Lanka. In: National Red List 2012 of Sri Lanka. Conservation status of the fauna and flora, Weerakoon, D.K., Wijesundara, S. (Eds.), Ministry of Environment, Colombo, Sri Lanka, pp. 411-430.

Tranter, D.J., Heron, A.C. 1968. Hydrodynamic tests on the prototype net of Working Party 2. In: Zooplankton sampling: review papers of the proceedings of the symposium on the hydrodynamics of zooplankton sampling. Monographs on Oceanographic Methodology, 2. pp. 170-171.
Wargo, A.M., Tilburg, C.E., Driggers, W.B., Sulikowski, J.A. 2009. Observations on the distribution of ichthyoplankton within the Saco River Estuary System. Northeastern Naturalist 16:647-654. https://doi.org/10.1656/045.016.n414

Wimalasiri, H.B.U.G.M., Weerakoon, W.R.W.M.A.P., Jayasinghe R.P.P.K., Dalpadado, P. 2021. Spatial patterns and key drivers of zooplankton in the north central Indian Ocean. Marine Biology Research https://doi.org/10.1080/17451000.2021.1975755

Yapa, K.K.A.S. 2012. Effect of surface wind and wind vectors on sea surface chlorophyll a distribution in the ocean waters surrounding Sri Lanka for the period 1999-2003. Journal of the National Science Foundation of Sri Lanka 40:221-229. https://doi.org/10.4038 /jnsfsr.v40i3.4696

Zacardi, D.M., da Ponte, S.C.S., Ferreira, L.C., de Lima, M.A.S., Silva, A.J.S, Chaves, C.S. 2017. Diversity and spatio-temporal distribution of the ichthyoplankton in the lower Amazon River, Brazil. Biota Amazonia 7:12-20. 


\begin{tabular}{|c|c|c|c|}
\hline Index & Equation & Description & References \\
\hline $\begin{array}{l}\text { Shannon-Wiener } \\
\text { diversity index }\end{array}$ & $H=-\sum_{i=1}^{\mathrm{S}}(p i \ln p i)$ & $\begin{array}{l}\text { S is the total number of the species, and } \\
\text { pi is the relative abundance ( } n_{i} / N \text { ) of each } \\
\text { species (where } n_{i} \text { is the number of } \\
\text { individuals in species } i_{\text {, } N \text { is total number }} \\
\text { of individuals in the collection) }\end{array}$ & $\begin{array}{l}\text { Shannon and } \\
\text { Weaver, } 1949\end{array}$ \\
\hline Simpson index & $D=1-\sum \frac{n_{i}\left(n_{i}-1\right)}{N(N-1)}$ & $\begin{array}{l}n_{i} \text { is the number of individuals in species } i \text {, } \\
N \text { is total number of individuals in the } \\
\text { collection }\end{array}$ & Simpson, 1949 \\
\hline Evenness & $J=\frac{H}{\ln S}$ & $\begin{array}{l}H \text { is species diversity and } S \text { is the total no. } \\
\text { of species }\end{array}$ & Pielou, 1966 \\
\hline Dominance & Dominance $=1-J$ & $J$ is the evenness & Balkate, 2017 \\
\hline Richness & Richness $=\frac{S-1}{\log n}$ & $\begin{array}{l}\text { Sis the total no. of species whereas } n \text { is } \\
\text { the total no. of individuals in the } \\
\text { community }\end{array}$ & Margalef, 1958 \\
\hline
\end{tabular}

